\title{
Greenhouse gas emission from the total process of swine manure composting and land application of compost
}

\author{
Jia Zhong a , Yuansong Wei ${ }^{\mathrm{a}, *}$, Hefeng Wan ${ }^{\mathrm{a}}{ }^{\mathrm{b}}$, Yulong $\mathrm{Wu}{ }^{\mathrm{b}}$, Jiaxi Zheng ${ }^{\mathrm{a}}$, \\ Shenghui Han ${ }^{c}$, Bofu Zheng ${ }^{\text {b }}$ \\ a Research Center for Eco-Environmental Sciences, Chinese Academy of Sciences, Beijing 100085, China \\ b Nanchang University, Nanchang 330031, China \\ ${ }^{\mathrm{c}}$ Institute of Atmospheric Physics, Chinese Academy of Sciences, Beijing 100029, China
}

\section{H I G H L I G H T S}

- The GHG emission factors of swine manure compost \& land application were developed.

- The GHG emission factors of this case study are lower than that of IPCC.

- The GWP was dominated by $\mathrm{CH}_{4}$ in the composting, land application emitted most $\mathrm{N}_{2} \mathrm{O}$.

\section{A R T I C L E I N F O}

\section{Article history:}

Received 22 February 2013

Received in revised form

24 August 2013

Accepted 27 August 2013

\section{Keywords:}

Greenhouse gas emission

Compost

Land application

Pig manure

Life cycle assessment

\begin{abstract}
A B S T R A C T
Greenhouse gas (GHG) emissions from animal manure management are of great concern in China. However, there are still great uncertainties about China's GHG inventory due to the GHG emission factors partly used default values from the Intergovernmental Panel of Climate Change (IPCC) guidelines. The purpose of this study was to use a case study in Beijing to determine the regional GHG emission factors based on the combination of swine manure composting and land application of the compost with both on-site examination and a life cycle assessment (LCA). The results showed that the total GHG emission factor was $240 \mathrm{kgCO}_{2} \mathrm{eq} \mathrm{tDS}{ }^{-1}$ (dry solids), including the direct GHG emission factor of $115 \mathrm{kgCO}_{2} \mathrm{eq}$ tDS ${ }^{-1}$ for swine manure composting and $48 \mathrm{kgCO}_{2} \mathrm{eq} \mathrm{tDS}{ }^{-1}$ for land application of the compost. Among the total GHG emissions of $5.06 \mathrm{kgCH}_{4} \mathrm{tDS}^{-1}$ and $0.13 \mathrm{kgN}_{2} \mathrm{O} \mathrm{tDS}{ }^{-1}$, the swine manure composting contributed approximately $89 \%$ to $\mathrm{CH}_{4}$ emissions while land application accounted for $92 \%$ of $\mathrm{N}_{2} \mathrm{O}$ emission. Meanwhile, the GHG emission profile from the full process in Beijing in 2015 and 2020 was predicted by the scenario analysis. The composting and land application is a cost-effective way for animal manure management in China considering GHG emissions.
\end{abstract}

(c) 2013 Elsevier Ltd. All rights reserved.

\section{Introduction}

The intensive livestock industry in China sharply increased pig output by 60\% from 2000 to 2010 (Ministry of Agriculture of China, 2011), and the amount of animal waste produced increased consequently. According to the National Census on Pollution Sources (Environmental Protection Agency of China, 2010), the total amount of animal waste produced was 243 million metric tons in 2007, and part of the discharged water pollutants accounted for $42 \%$ of the total $\mathrm{COD}_{\mathrm{Cr}}$ (Chemical Oxygen Demand) and $22 \%$ of total nitrogen (TN) of wastewater nationwide. Moreover, cattle and swine manure are

\footnotetext{
* Corresponding author. Tel.: +86 010 62849109; fax: +86 01062843276 .

E-mail addresses: yswei@rcees.ac.cn, will.yswei@gmail.com (Y. Wei).
}

among the major contributors to greenhouse gases (GHG) and global warming potential (GWP). The Second National Communication on Climate Change (2013) revealed that $\mathrm{CO}_{2}$ equivalents from livestock manure management in China in 2005 were 4.34 times more than the emission estimate of the year 1994 (National Development and Reform Commission, 2004). However, there is still great uncertainty about the national GHG inventory derived from waste management in China. On one hand, the GHG emission factors from animal waste management used in the inventory analysis of China were based on default values recommended by the IPCC, whose data were from a few literature sources (IPCC, 2006a). On the other hand, GHG emission factors from animal waste management based on on-site observations in China was lacking.

As a cost-effective way to treat and reutilize organic wastes such as animal waste (Kumar, 2011), composting and compost land 


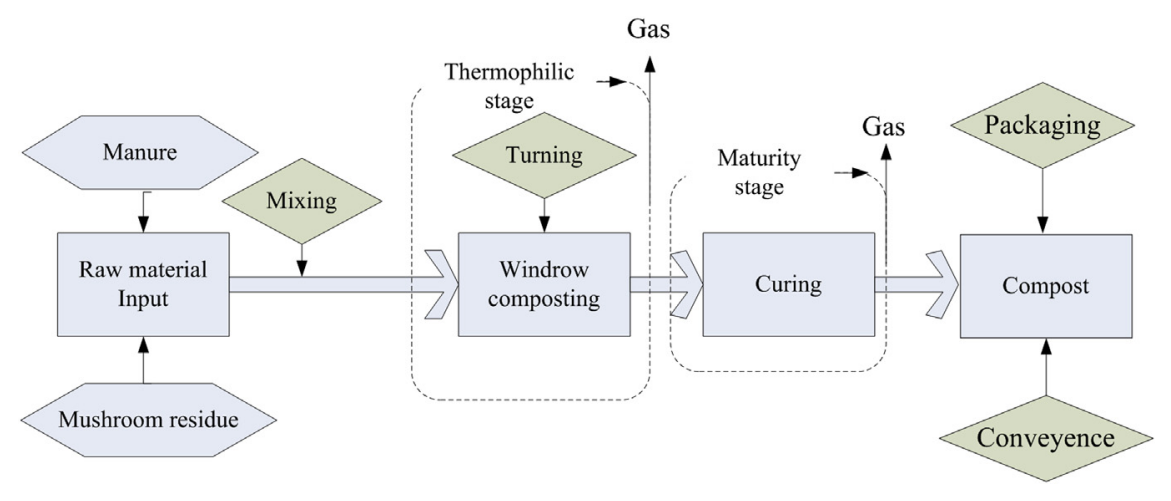

Fig. 1. The technical roadmap of windrow composting at the farm scale.

application for agriculture is encouraged and promoted in China, e.g., a policy of technological control for livestock and poultry pollution (Ministry of Environmental Protection of China, 2011) was officially issued in 2011. Of the total farm fields in China, $12 \%$ were vegetable fields, which were generally applied with fertilizer or compost (Ministry of Agriculture of China, 2011). Organic fertilizer such as manure compost, which is low in $\mathrm{N}$ content and high in organic matters, was widely used as a soil conditioner to amend the soil structure and complement organic matter. It is estimated that the potential organic fertilizer resources of 3.05 million metric tons of N, 1.40 million metric tons of $\mathrm{P}_{2} \mathrm{O}_{5}$ and 2.95 million metric tons of $\mathrm{K}_{2} \mathrm{O}$ like compost ( $\mathrm{Li}, 2011$ ) could possibly make up the gap of imported inorganic fertilizer of 0.44 million metric tons per year (Ministry of Agriculture of China, 2011). Although 74\% of $\mathrm{N}_{2} \mathrm{O}$ emissions in China were due to direct emission from agricultural activity (National Development and Reform Commission, 2013), compost land application was also considered as a temporary reserve for GHG. The application of compost to agricultural land has been reported to increase soil carbon (C) content, and is regarded as a means of $C$ sequestration (Smith et al., 1998).

GHG emissions from composting of manure (Czepiel et al., 1996), other organic wastes (Recycled Organics Unit, 2006; USEPA, 2002), and land application of compost (Whalen et al., 2008) had been widely studied. However, these studies paid little attention to their global warming potential. Many greenhouse gas emission calculations were oriented towards fuel combustion by facilities and machines (Suh and Rousseaux, 2002), but the composting pile has a greater emission potential for climate change (Butler and Hooper, 2010; Kumar, 2011). The GHG emissions from fertilization practices in crop production were influenced by the key factors of N uptake efficiency (Novak and Fiorelli, 2010) and the enhancement of soil organic carbon (SOC) remediation (Smith et al., 1998). However, current research on GHG calculation combining composting operation and land application of compost is rare, whereas existing research that draws on field tests has been mostly focused on rice paddies, wheat and maize rather than vegetable fields (Pei et al., 2011).

Another fact leading to the great uncertainty over the GHG inventory from waste management in China is extremely lack of onsite GHG observation data. Most of the relevant research was conducted at pilot scale (Fukumoto et al., 2003; Hao et al., 2001; Jiang et al., 2011) rather than at large scale. Moreover, few studies undertake integrated analysis of the total process of animal manure composting and land application of the manure compost, including mechanical operation and power supply as a whole system (Thelen et al., 2010). Therefore the purpose of this study was to determine GHG emission factors from the total process of swine manure composting and land application of compost through on-site observations and a life cycle assessment using a case study in Beijing,
China. Both uncertainty and scenario analyses related to the case study's GHG emissions were conducted.

\section{Materials and methods}

\subsection{Field test}

An animal manure composting plant and a vegetable field applied by manure compost from an intensive swine farm were investigated in this study. The animal manure composting plant, which has an area of 1.34 ha, annually produces about 4.0 thousand metric tons of manure compost (25\% of moisture content) using windrow composting technology as shown in Fig. 1. The composting plant operates in a typical mode with a total of 24 windrows, each of which is $75.00 \mathrm{~m}$ long, $2.00 \mathrm{~m}$ wide and $0.90 \mathrm{~m}$ high (50 t of treating capacity per windrow). The windrow composting period usually includes a thermophilic stage ( $2-3$ weeks) and a maturity stage (nearly one month). The manure compost product is sold as an organic fertilizer for soil amendment.

In this study, the investigation of the entire process of animal manure composting and land application of the compost included 53 days of swine manure composting from May to July in 2011 and 68 days of land application of the compost in a lettuce (Lactuca sativa L.) field from December 2011 to February 2012, respectively. The manure was collected in daily routine from the hogpen, while the mushroom residue was transported from the mushroom plant nearby. The experimental windrow composting pile had a capacity of $25 \mathrm{t}$ with a size of $35.00 \mathrm{~m} \times 2.00 \mathrm{~m} \times 0.90 \mathrm{~m}(\mathrm{~L} \times \mathrm{W} \times \mathrm{H})$. The manure and the mushroom (Table 1 ) were mixed at a ratio of $2: 1(v / v)$ by a front loader (LW160, Xugong, China). The raw manure was representative due to similar characteristics to studies of manure composting in Beijing (Table S1). The windrows were then built up by a front loader and

Table 1

Characteristics of main raw materials of swine manure composting.

\begin{tabular}{|c|c|c|c|c|c|}
\hline \multirow[t]{2}{*}{ Characteristics } & \multicolumn{3}{|c|}{ Composting } & \multicolumn{2}{|c|}{ Land application } \\
\hline & $\begin{array}{l}\text { Swine } \\
\text { manure }\end{array}$ & $\begin{array}{l}\text { Mushroom } \\
\text { residues }\end{array}$ & $\begin{array}{l}\text { Mixture } \\
\text { (Initial) }\end{array}$ & Compost & $\begin{array}{l}\text { Background } \\
\text { soil }\end{array}$ \\
\hline $\mathrm{pH}$ & 8.11 & 6.21 & 7.27 & 9.79 & 8.67 \\
\hline $\begin{array}{l}\text { Moisture } \\
\text { content (\%) }\end{array}$ & 72.02 & 45.00 & 47.80 & 22.58 & 15.94 \\
\hline $\begin{array}{l}\text { Bulk density } \\
\qquad\left(\mathrm{kg} \mathrm{m}^{-3}\right)\end{array}$ & 993.10 & 190.21 & - & - & 960.51 \\
\hline $\mathrm{TC}^{\mathrm{a}}\left(\mathrm{g} \mathrm{kgDS}^{-1}\right)$ & 331.42 & 395.28 & 223.62 & 202.86 & 25.50 \\
\hline $\mathrm{TN}^{\mathrm{a}}\left(\mathrm{g} \mathrm{kgDS}^{-1}\right)$ & 25.98 & 22.55 & 20.63 & 21.84 & 1.99 \\
\hline $\mathrm{TP}^{\mathrm{a}}\left(\mathrm{g} \mathrm{kgDS}^{-1}\right)$ & 12.01 & 4.69 & 16.77 & 18.45 & 1.66 \\
\hline $\mathrm{C}: \mathrm{N}$ ratio & 12.75 & 17.53 & 14.86 & 9.29 & 12.78 \\
\hline
\end{tabular}

TN - Total Nitrogen; TP - Total Phosphorus.

a Measured based on dry matter. 


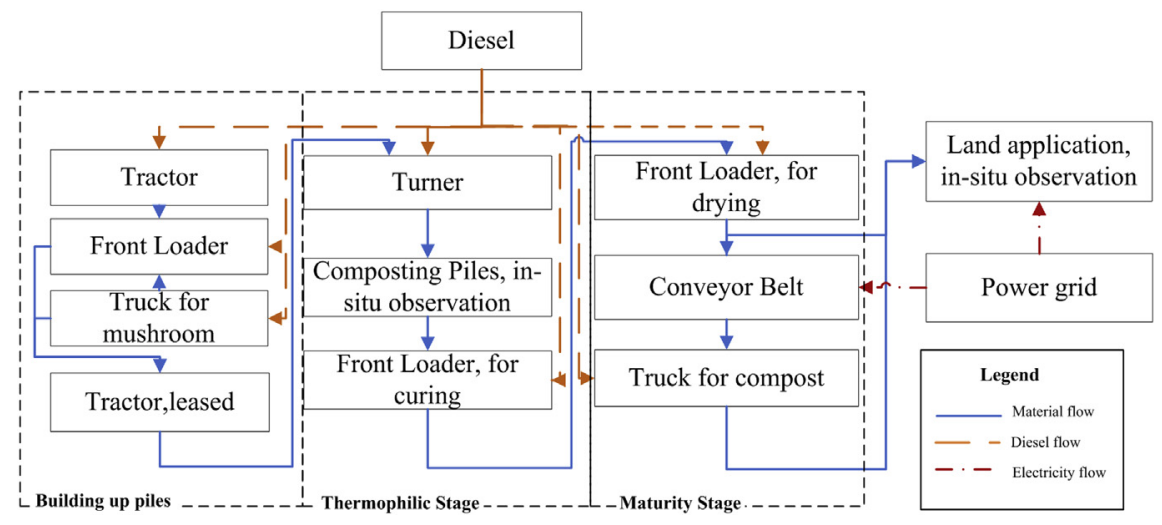

Fig. 2. Model framework of the system in $\mathrm{Gabi}^{\circledR} 4.4$.

turned once a week by a turner (Backhus, 15.3, Germany) during the thermophilic stage, and stacked up in the maturity stage. According to the practical investigation, the final mass reduction of the composting materials was approximately $33 \%$, which was conformed to the value calculated from the equation with nonvolatile solid with mass reduction rate (Breitenbeck and Schellinger, 2004). The field test of compost land application was carried out in a vegetation greenhouse planted with $L$. sativa $\mathrm{L}$. at density of 36 plants $\mathrm{m}^{-2}$. Before the $L$. sativa $L$. was transplanted into the test fields, the soil was applied uniformly with bed fertilizer harrowed in and then dried for 3 days. Fertilization of the vegetation followed local cultivation tradition at $113 \mathrm{gN} \mathrm{m}^{-2}$ of compost application rate. There were 3 parallel test fields of $3.00 \mathrm{~m}^{2}$ $(2.00 \mathrm{~m} \times 1.50 \mathrm{~m})$ randomly distributed in a larger area of $36 \mathrm{~m}^{2}$ and separated by $30 \mathrm{~cm}$ of PVC embedded into the soil. The soil was surface irrigated for 5 times throughout the cultivation. The physi-chemical characteristics of the soil and manure compost are listed in Table 1

\subsection{Sampling and analysis}

Gas samples were collected using the static chamber method by continuous collection 4 times every 3 min during swine manure composting and 5 times every 5 min during land application of manure compost, respectively. The windrow evenly fall into 4 sections with 4 chambers located at the middle point of each section as replicates. Airtight syringes $(60 \mathrm{~mL})$ were used to take gas samples from a rectangular chamber (14.28 L with a size of $35 \mathrm{~cm} \times 24 \mathrm{~cm} \times 17 \mathrm{~cm}$ for the windrow composting, and $125 \mathrm{~L}$ with a size of $50 \mathrm{~cm} \times 50 \mathrm{~cm} \times 50 \mathrm{~cm}$ for the compost land application). During swine manure composting, the GHG gases were sampled intermittently for the first 7 days followed by days $10,14,16,23,38$, and 53 , while it was every day for the first 10 days followed by days $14,17,20,23,26,47,49,54,57$, and 58 during $L$. sativa L. cultivation. The $\mathrm{CH}_{4}$ and $\mathrm{N}_{2} \mathrm{O}$ concentrations of the gas samples were simultaneously analyzed by a flame ionization detector (FID) and an electron capture detector (ECD) in the gas chromatograph (Agilent ${ }^{\circledR} 4980$, USA), respectively. Detailed detection was included in Supporting Information (SI).

\subsection{Life cycle assessment (LCA)}

The GHG emission from the total process of swine manure composting and land application of the compost was calculated by the LCA method using the Gabi ${ }^{\circledR} 4.4$ software (PE International, Stuttgart, Germany). In addition to direct GHG emissions, the indirect GHG emissions from energy sources such as diesel and electricity consumption were also considered within the system boundaries. The operating parameters of each device in this study are listed in
Table S2. Therefore the whole system could be divided into six subprocesses: transportation, composting operation, composting pile emission, land application emission, power grid, and diesel supply.

Two calculation principles were followed in this study: the Reference Flow and Mass Balance. The Reference Flow principle (i.e., mass flows and energy flows) tracks the material treated and the energy consumed in and from the processes on the basis of the functional unit. Mass Balance ensures the equivalence of input and output flows in each subprocess except for composting due to the mass reduction of wastes. An impact factor system (updated in 2001) was used, including global warming potential (GWP, 100 years) (Guinée, 2002; Institute of Environmental Sciences, 2010). Definitions required for the LCA system in this study were specified as follows:

(i) System boundary: The scope of this case study included GHG emissions $\left(\mathrm{CH}_{4}, \mathrm{~N}_{2} \mathrm{O}\right.$, and fossil $\left.\mathrm{CO}_{2}\right)$ from direct and indirect sources within the physical border of the manure composting plant in the year 2011. Biogenic $\mathrm{CO}_{2}$ and other GHGs are excluded when decomposition of neutral biogenic materials does not appreciably add to atmospheric carbon concentration (USEPA, 2011) while other GHGs were almost undetectable. GHG emissions from both owned and leased equipment were included to track the contribution of diesel and electric consumption. The power grid and diesel supply from upstream processes were also involved. The model framework for this study is shown in Fig. 2.

(ii) Functional Unit: It was defined as the composting and land application of 1 metric ton of raw manure on a dry solids basis.

(iii) Data quality: The major GWP impact category in this study was climate change shown as $\mathrm{CO}_{2}$ equivalents. Therefore, data related to GHGs in this study were from four sources: (1) onsite observations of $\mathrm{CH}_{4}$ and $\mathrm{N}_{2} \mathrm{O}$ during swine manure composting and land application of the compost; (2) database of $\mathrm{Gabi}^{\circledR}$ database from which transportation truck units and diesel supply units were selected according to European Emission Standards 3 and 4 (European Parliament Council, 2000); (3) theoretical calculations of the total global warming impact by the accumulating emission factors and activity levels; and (4) reports providing fossil $\mathrm{CO}_{2}$ emission factors for the power grid per kilowatt-hour of electricity and data sources of uncertainty analysis from the literature (listed in SI).

\subsection{Uncertainty analysis}

Some uncertainties may remain within the GHG emission factors with respect to raw materials, pile temperature, $\mathrm{C} / \mathrm{N}$ ratio, 


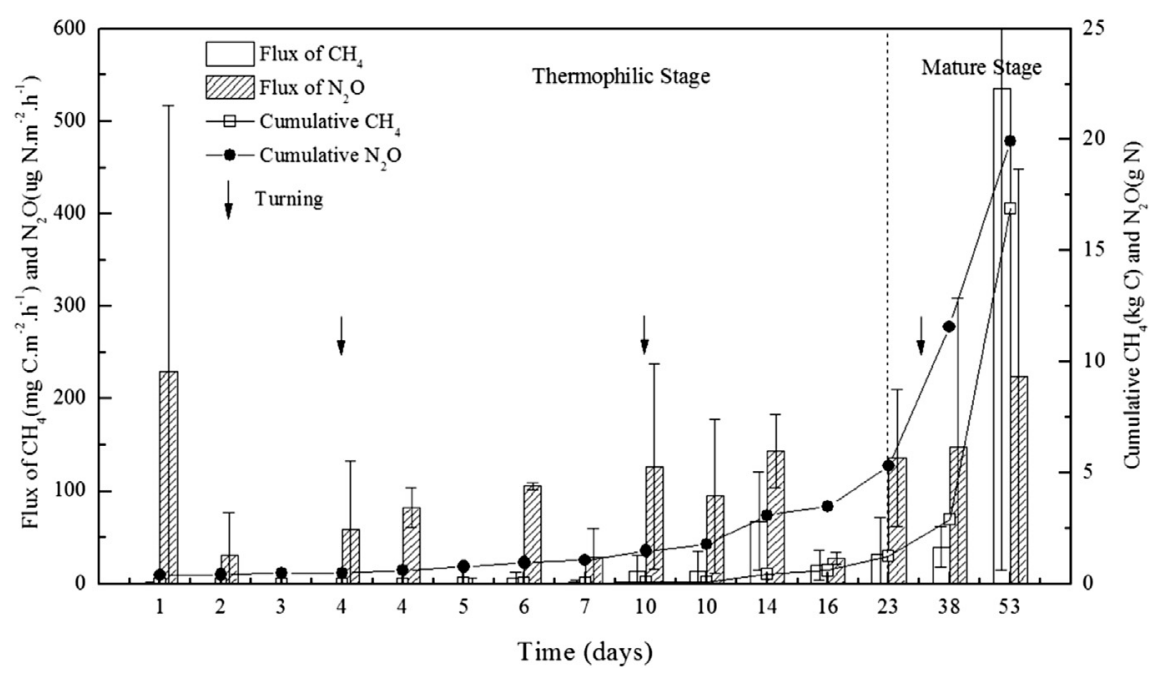

Fig. 3. Fluxes and cumulative emissions of $\mathrm{N}_{2} \mathrm{O}$ and $\mathrm{CH}_{4}$ during composting.

moisture content, turning frequency, and compost application rate. Therefore, a Monte-Carlo simulation was carried out to minimize the overall uncertainty and to determine the variance of the GWP resulting from the input parameters. By defining the range and randomly generating the values of input variables from a Gaussian distribution in Gabi ${ }^{\circledR} 4.4$ over 400 times, the GWP values were computed with a relative standard deviation distribution (RSD) based on around the GWP results derived from our case study. Twelve input variables (Table S3) were considered in the uncertainty analysis, of which the minimum, maximum and deviation values were used from this study's results. Literature data (Table S4 and Table S5) relevant to on-site GHG emission factors from composting and land application of compost were selected to define the variations in GHG emission factors.

\subsection{Scenario analysis}

The GHG emission scenario analysis of swine manure composting and land application of compost in this study was simulated for the next $5-10$ years, and this time frame will be a primary concern for both the livestock industry and composting facilities to maintain their sustainability.

As expressed in Equation (1), $H$ represents the number of output pigs (10 thousand heads) as shown in Equation (2) of Section 3.2.3, reflecting the agricultural development and population growth. $R$ (\%) is the composting treatment rate of animal manure, and the potential GHG emission factors $\left(E F, \mathrm{kgCO}_{2} \mathrm{eq} \mathrm{tDS}^{-1}\right)$ come from the Monte-Carlo simulation. $D C$ is the manure discharge coefficient for fattening output pigs (660.65 $\mathrm{kg}$ head $^{-1}$ year $^{-1}$, wet weight) from the national database (Dong et al., 2011; Environmental Protection Agency of China, 2010), and $100 \%-w_{\mathrm{H}_{2} \mathrm{O}}$ is the solid content of manure (\%).

$\mathrm{GHG}_{\text {senario }}=H \times R \times E F \times D C \times\left(100 \%-w_{\mathrm{H}_{2} \mathrm{O}}\right)$

There are several assumptions made for this scenario analysis: 1 ) the solid content of raw swine manure is 30\% (Chinese Agricultural University, 1997); 2) $R$ was assumed at three levels $(10 \%, 30 \%$, and $50 \%)$ as different treatment scenarios based on the current treatment scale (Lian, 2010); 3) 100\% of the compost was applied to the land as its end use; and 4) the baseline year was set in 2011.

\subsection{Life cycle cost analysis}

The cost-benefit analysis of this case study, including energy consumption, freight, rent, labor and net profit from the compost product, was carried out by a life cycle-based cost method (LCC). Due to inadequate access to the capital costs of constructing the composting plant and greenhouses, only the operational costs were considered in this study. In addition, the vegetable cultivation within the composting plant was a low-cost endeavor. Therefore, five parts of the LCC analysis in this study are energy and fuel consumption, freight costs for trucks, rent for the leased tractor, labor costs and packaging. The power was supplied at a cost of US\$ $0.11(\mathrm{~kW} \mathrm{~h})^{-1}$ (US\$ $\left.1=\mathrm{RMB} 6.366\right)$. The fuel price was referenced to the current diesel price of US\$ $1.46 \mathrm{~L}^{-1}$. The freight cost consisted of raw materials (US\$23.56 $\mathrm{t}^{-1}$ ) and compost (US\$ $6.28 \mathrm{t}^{-1}$ ) transportation by trucks. Rents for tractors were paid on time at US\$ 47.12 per hour. The annual salary of a worker ( 10 workers in the factory) was US\$3768. Each package of the compost costs US\$ 0.25 $\left(50 \mathrm{~kg}\right.$ package $\left.\mathrm{e}^{-1}\right)$. A government subsidy was provided at US\$ $18.85 \mathrm{t}^{-1}$ compost (moisture content at $25 \%$ ).

\section{Results and discussion}

\subsection{GHG emissions}

\subsubsection{Composting of swine manure}

Windrow composting is done by setting up long rows of biodegradable wastes subject to decomposition with aeration by periodic turning (Shi et al., 1999). As shown in Fig. 3, the first thermophilic stage lasted 23 days, when $\mathrm{N}_{2} \mathrm{O}$ flux decreased from a flux peak of $230 \mu \mathrm{gN} \mathrm{m} \mathrm{m}^{-2} \mathrm{~h}^{-1}$ on the first day, but steadily rose afterward as did levels of $\mathrm{CH}_{4}$. The major contribution to GHG production occurred during the last 30-day of maturity stage, when the peak values of $\mathrm{CH}_{4}$ and $\mathrm{N}_{2} \mathrm{O}$ emerged on the final day (day 53) at $535 \mathrm{mgC} \mathrm{m}^{-2} \mathrm{~h}^{-1}$ and $224 \mu \mathrm{gN} \mathrm{m} \mathrm{m}^{-2} \mathrm{~h}^{-1}$, respectively. The cumulative $\mathrm{N}_{2} \mathrm{O}$ and $\mathrm{CH}_{4}$ emissions in this maturity stage accounted for $73 \%$ and $93 \%$, respectively, of the total accumulated emission amount. The emission factors for $\mathrm{CH}_{4}$ and $\mathrm{N}_{2} \mathrm{O}$ were $4.51 \mathrm{kgCH}_{4} \mathrm{tDS}^{-1}$ (dry manure) and $6.26 \times 10^{-3} \mathrm{kgN}_{2} \mathrm{O} \mathrm{tDS}^{-1}$, respectively. Even though the GWP of $\mathrm{N}_{2} \mathrm{O}$ (298 times the equivalent amount of $\mathrm{CO}_{2}$ ) is 12 times more than that of $\mathrm{CH}_{4}$ (25 times the equivalent amount of $\mathrm{CO}_{2}$ ), the $\mathrm{CO}_{2}$ equivalents of $\mathrm{N}_{2} \mathrm{O}$ were minimal and amounted to only $1.6 \%$ of the total $\mathrm{CO}_{2} \mathrm{eq}$. 
In this study, the total accumulated $\mathrm{C}$ and $\mathrm{N}$ losses in the form of GHG emissions were $16.90 \mathrm{kgC}(0.58 \%$ of the initial TC of the compost mixture, $\mathrm{TC}_{\mathrm{ini}}$, dry basis) and $19.93 \mathrm{gN}$ (less than $0.01 \%$ of initial TN of compost mixture, $\mathrm{TN}_{\mathrm{ini}}$, dry basis), respectively. Though a higher TN content resulted in low $\mathrm{C}: \mathrm{N}$ ratio, the lower $\mathrm{pH}$ value might result in a relatively lower $\mathrm{N}_{2} \mathrm{O}$ emission loss (Law et al., 2011). Other studies also took $\mathrm{N}_{2} \mathrm{O}$ emission in concern (Huang et al., 2010; Wu et al., 2012). $\mathrm{N}_{2} \mathrm{O}$ was detected in the early and maturity stages of windrow composting in a pilot scale of $7.70 \mathrm{~m}$ in length (Hao et al., 2001) with $\mathrm{C}$ and $\mathrm{N}$ losses of $0.81 \% \mathrm{TC}_{\mathrm{ini}}$ and $0.019 \%$ of $\mathrm{TN}_{\mathrm{ini}}$, respectively. Two other manure windrow systems (straw-rich and wood-chip mixture) in Hao's study (2004) showed comparatively higher emission losses $\left(\mathrm{CH}_{4}-\mathrm{C}\right.$ : $2.7 \%$ of $\mathrm{TC}_{\text {ini }}$ for straw-mixture and $2.0 \%$ of $\mathrm{TC}_{\text {ini }}$ for woodchips; $\mathrm{N}_{2} \mathrm{O}-\mathrm{N}$ : $0.39 \%$ of $\mathrm{TN}_{\text {ini }}$ for straw and $0.68 \%$ of $\mathrm{TN}_{\text {ini }}$ for woodchips-mixture). A comparable loss of $2.12 \%$ of $\mathrm{TN}_{\text {ini }}$ in the $\mathrm{N}_{2} \mathrm{O}-\mathrm{N}$ form was from an $11 \mathrm{~m}$ long manure windrow composting compared to a $1.53 \% \mathrm{~N}$-loss from an aerated static system of sewage sludge composting (Czepiel et al., 1996). Meanwhile yard waste and sludge windrow reported a $0.1 \%-2.2 \%$ of total $\mathrm{N}$ loss due to $\mathrm{N}_{2} \mathrm{O}$ (Barton and Atwater, 2002). However, these measured values of direct GHG emissions were lower than the published default values (10 $\mathrm{kgCH}_{4} \mathrm{tDS}^{-1}$ and $0.6 \mathrm{kgN}_{2} \mathrm{O} \mathrm{tDS}^{-1}$ ) from the IPCC (2006b). And most of the GHG emission factors from literature of animal manure composting listed in Table S6 were higher than those of this study.

\subsubsection{Land application of swine manure compost}

GHG emissions during a 2-month cultivation of $L$. sativa $\mathrm{L}$. applied with swine manure compost are shown in Fig. 4. The $\mathrm{CH}_{4}$ flux rose sharply after day 26 when the moisture content of the soil decreased to its average level of $26 \%$, and the flux of $\mathrm{N}_{2} \mathrm{O}$ steadily fell off from the beginning of cultivation. In the first growth stage (26 days) of $L$. sativa $\mathrm{L}$., $73 \%$ of $\mathrm{N}_{2} \mathrm{O}-\mathrm{N}$ and $3.2 \%$ of $\mathrm{CH}_{4}-\mathrm{C}$ were lost. The total $\mathrm{N}$ and $\mathrm{C}$ loss due to GHG emissions from the land application of swine manure compost were $732 \mathrm{mgN}$ ( $0.2 \%$ of TN in compost, dry basis) and $3604 \mathrm{mgC}$ ( $0.1 \%$ of TC in compost, dry basis), respectively, and $\mathrm{N}_{2} \mathrm{O}$ surpassed $\mathrm{CH}_{4}$ as the key contributor to GHG emissions. Hence the GHG emission factors from the vegetable cultivation were calculated at $0.50 \mathrm{kgCH}_{4} \mathrm{tDS}^{-1}$ and $0.12 \mathrm{kgN}_{2} \mathrm{O} \mathrm{tDS}^{-1}$, respectively. Addition of compost promoted the $\mathrm{N}_{2} \mathrm{O}$ while the soil moisture content regulated the $\mathrm{CH}_{4}$ emission. Borken et al. (2006) explained that the moisture content of the soil may increase $\mathrm{CH}_{4}$ uptake by methanotrophs, which are sensitive to water stress, and $\mathrm{CH}_{4}$ absorption was significantly reduced by drier conditions with limited methanotroph activity (Liu et al., 2008). This would possibly result in the $\mathrm{CH}_{4}$ emission peak due to drying soil.
A similar result for $\mathrm{N}_{2} \mathrm{O}$ emission from a greenhouse vegetable system in northern China (Pei et al., 2011) was reported with $0.27-$ $0.30 \% \mathrm{~N}$ loss of the nitrogen input, of which $57-94 \%$ was from $\mathrm{N}_{2} \mathrm{O}$ emissions in the initial growth stage. Another greater loss of $0.73 \%$ $\mathrm{N}_{2} \mathrm{O}-\mathrm{N}$ was observed from a Nanjing vegetable field due to humid weather (Xiong et al., 2006). However, the default $\mathrm{N}_{2} \mathrm{O}$ emission factors for agricultural soils applied with organic additions or livestock excretion deposits are $1 \%$ and $2 \%$ of TN input, respectively, in the national inventory guidelines (IPCC, 2006c). These values are 3-6 times higher than the $\mathrm{N}_{2} \mathrm{O}$ emission factors in this study $(0.34 \%$ of TN input), which would not be applicable in case of GHG inventory calculation.

\subsubsection{Mass Balance of $\mathrm{CH}_{4}$ and $\mathrm{N}_{2} \mathrm{O}$}

The GHG emission factors in $\mathrm{CO}_{2}$ equivalents base were $115 \mathrm{kgCO}_{2} \mathrm{eq} \mathrm{tDS}^{-1}$ from swine manure composting $\left(4.51 \mathrm{kgCH}_{4} \mathrm{tDS}^{-1}\right.$ and $6.26 \times 10^{-3} \mathrm{kgN}_{2} \mathrm{O} \mathrm{tDS}^{-1}$ ) and $48 \mathrm{kgCO}_{2} \mathrm{eq} \mathrm{tDS}^{-1}$ from land application of the compost $\left(0.50 \mathrm{kgCH}_{4} \mathrm{tDS}^{-1}\right.$ and $\left.0.12 \mathrm{kgN}_{2} \mathrm{O} \mathrm{tDS}^{-1}\right)$. With the application of manure compost, the organic matter, TC and TN content in soil rose from $10.38 \%, 2.55 \%$ and $0.20 \%$ to $15.69 \%, 3.06 \%$ and $0.27 \%$, respectively, which resulted in $14.12 \%, 2.91 \%$ and $0.25 \%$ remained in the soil after the reap of $L$. sativa $L$.

Compost and manure additions could raise the soil's carbon level and improve N use efficiency (Novak and Fiorelli, 2010). The potential benefits of integrating livestock and cropping systems had been considered to enhance the net GHG remediation of $-784 \mathrm{gCO}_{2} \mathrm{eq} \mathrm{m}^{-2}$ year $^{-1}$ by corn-soybean bioenergy production and soil carbon sequestration, compared to $52 \mathrm{gCO}_{2} \mathrm{eq} \mathrm{m}^{-2}$ year $^{-1}$ for non-manure amended check (Thelen et al., 2010).

\subsection{Life cycle assessment}

\subsubsection{Life cycle inventories and global warming potential}

The major input and output mass and energy reference flows of each subprocess during the full process were listed in Table 2 as the life-cycle inventory. As shown in Fig. 5, the transportation section contributed the most to diesel consumption and the rolling engine used in greenhouse was dominant in power consumption. In terms of the GHG emissions, $56 \%$ of fossil $\mathrm{CO}_{2}$ was from diesel consumption by vehicles, $89 \%$ of $\mathrm{CH}_{4}$ was from the swine manure composting process, and $92 \%$ of $\mathrm{N}_{2} \mathrm{O}$ was created by the land application of compost.

According to the inventory result, the total GHG emission factor of the complete process in this study was $240 \mathrm{kgCO}_{2} \mathrm{eq} \mathrm{tDS}^{-1}$ with contributions by $\mathrm{CH}_{4}(53 \%)$, fossil $\mathrm{CO}_{2}(31 \%)$, and $\mathrm{N}_{2} \mathrm{O}$ (16\%), respectively. The largest GHG emission contributions of subprocesses were

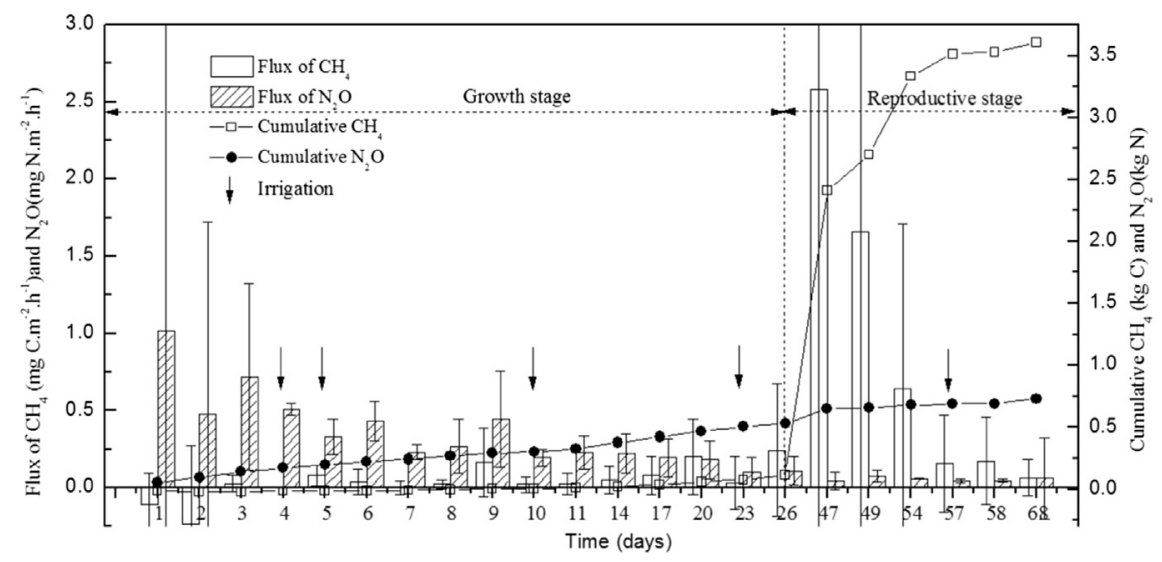

Fig. 4. Fluxes and cumulative emissions of $\mathrm{N}_{2} \mathrm{O}$ and $\mathrm{CH}_{4}$ from the land application of compost. 
Table 2

Life cycle inventory of the full process of swine manure composting and land application of compost.

\begin{tabular}{|c|c|c|c|c|c|c|c|}
\hline Parameter & Transportation & Composting operation & Composting pile & Land application & Power grid & Diesel supply & Total \\
\hline \multicolumn{8}{|l|}{ Main input } \\
\hline Materials $\left(\mathrm{kg} \mathrm{tDS}^{-1}\right)^{\mathrm{d}}$ & $\begin{array}{l}3574 \mathrm{~kg} \text { Raw Manure }+342 \mathrm{~kg} \\
\text { Mushroom residue }\end{array}$ & 3916 & 3916 & 2610 & - & - & - \\
\hline Diesel (kg tDS $\left.{ }^{-1}\right)$ & 8.91 & 3.89 & $0.00^{\mathrm{a}}$ & $0.00^{\mathrm{a}}$ & $0.00^{\mathrm{a}}$ & $0.00^{\mathrm{a}}$ & 12.80 \\
\hline Electricity (kJ) & $0.00^{\mathrm{a}}$ & 1370 & $0.00^{\mathrm{a}}$ & 58,800 & $0.00^{\mathrm{a}}$ & $0.00^{\mathrm{a}}$ & 601,700 \\
\hline \multicolumn{8}{|l|}{ Main output } \\
\hline $\mathrm{CO}_{2}\left(\mathrm{~kg} \mathrm{tDS}^{-1}\right)$ & 40.85 & 10.45 & $0.00^{\mathrm{b}}$ & $0.00^{\mathrm{b}}$ & 16.39 & 5.25 & 72.94 \\
\hline $\mathrm{CH}_{4}\left(\mathrm{~kg} \mathrm{tDS}^{-1}\right)$ & $4.04 \mathrm{E}-04$ & $5.55 \mathrm{E}-05$ & 4.51 & 0.50 & $0.00 \mathrm{c}$ & $5.48 \mathrm{E}-02$ & 5.06 \\
\hline $\mathrm{N}_{2} \mathrm{O}\left(\mathrm{kg} \mathrm{tDS}^{-1}\right)$ & $8.06 \mathrm{E}-04$ & $4.71 \mathrm{E}-05$ & $6.26 \mathrm{E}-03$ & 0.12 & $0.00 c$ & $9.02 \mathrm{E}-05$ & 0.13 \\
\hline Percentage of $\mathrm{CO}_{2} \mathrm{eq}(\%)$ & 17 & 4 & 48 & 20 & 7 & 3 & 100 \\
\hline
\end{tabular}

a No diesel or electricity was assumed to be consumed during the process.

b Biogenic $\mathrm{CO}_{2}$ was not addressed in this case.

c According to baseline emission factors of the regional power grid (Department of Climate Change and National Development \& Reform Commission of China, 2011), $\mathrm{CH}_{4}$ and $\mathrm{N}_{2} \mathrm{O}$ were excluded.

d Materials calculated at a 2:1 ratio of swine manure: mushroom $(v / v)$ on the basis of 1 ton dry swine manure; for the moisture content and bulk density of swine manure and mushrooms, please see Table 1.

from swine manure composting (48\%) and land application (20\%) followed in order of transportation (17\%), the power grid (7\%), the composting operation (4\%), and the diesel supply (3\%).

Due to the large GHG emission potential of composting, many research have been carried out to control and mitigate GHG emissions. Jiang et al. (2011) conducted a lab-scale manure composting mixed with cornstalks to investigate operational coefficients like $\mathrm{C} /$ $\mathrm{N}$ ratio, aeration rate, and initial moisture content. Their total value of $\mathrm{CO}_{2}$ eq emission ranged from 324 to $743 \mathrm{kgCO}_{2}$ eq $\mathrm{tDS}^{-1}$ (aeration power included), and a lower $\mathrm{C} / \mathrm{N}$ ratio was considered to be the effective factor in $\mathrm{CH}_{4}$ and $\mathrm{NH}_{3}$ reduction. The results also indicated that the aeration rate reduced the GHG emission from $747 \mathrm{kgCO}_{2} \mathrm{eq} \mathrm{tDS}^{-1}$ to $546 \mathrm{kgCO}_{2} \mathrm{eq} \mathrm{tDS}^{-1}$, however the GHG emission due to power consumption (which increases) rose from $5 \%$ to $23 \%$ of the total $\mathrm{CO}_{2}$ eq emission. Park et al. (2011) compared $\mathrm{CH}_{4}$ and $\mathrm{N}_{2} \mathrm{O}$ fluxes using four manure composting forms mixed with sawdust (forced aeration, wire mesh, turning, and no aeration). Among these techniques, the turning system had the highest GHG emission factor of $155 \mathrm{kgCO}_{2} \mathrm{eq} \mathrm{tDS}{ }^{-1}$, similar to that in this study $\left(115 \mathrm{kgCO}_{2} \mathrm{eq} \mathrm{tDS}^{-1}\right)$. Another large scale case based on composting of household organic waste and green waste in Italy showed a net GHG emissions at $130 \mathrm{kgCO}_{2}$ eq per ton of the original bio-wastes (Blengini, 2008) with $\mathrm{CO}_{2}$ compensated by the avoidance of fertilizers ( $48 \mathrm{~g} \mathrm{~kg}^{-1}$ mixed waste) and $\mathrm{CO}_{2}$ sequestration (48 $\mathrm{g} \mathrm{kg}^{-1}$ mixed waste).

\subsubsection{Uncertainty analysis}

The result of uncertainty analysis was shown in Fig. 6. The GWP simulation results ranged from $-20 \%$ to $+90 \%$ RSD of the obtained

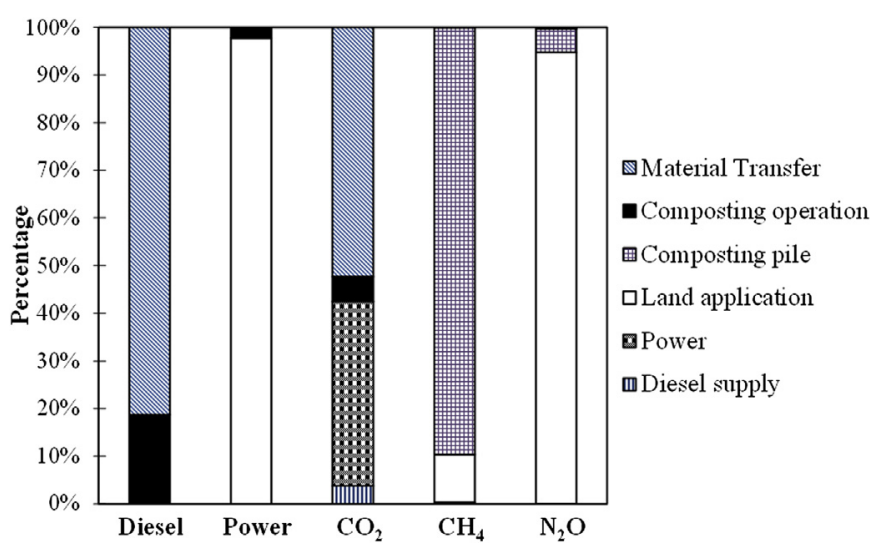

Fig. 5. Major input and output reference flows of each subprocess.
GHG emission factor at $240 \mathrm{kgCO}_{2} \mathrm{eq} \mathrm{tDS}{ }^{-1}$ (0\% RSD) in Gauss distribution. A percent of $88 \%$ of all the simulated values were higher than the $0 \% \mathrm{RSD}$, and the mean value was $300 \mathrm{kgCO}_{2} \mathrm{eq} \mathrm{tDS}^{-1} \pm 13 \%$ RSD as discussed below in the scenario analysis.

\subsubsection{Scenario analysis}

In the scenario analysis of this study, two key factors should be considered as the composting rate of swine manure $(R)$ and the number of output pigs $(H)$. Three composting rate levels of $10 \%, 30 \%$ and 50\% were assumed in the years 2011, 2015, and 2020 respectively. Due to the difficulty of predicting the future of the livestock and poultry industry, e.g., the outbreak of foot-and-mouth disease abruptly cut the number of output pigs between the years of 2005 and 2007 (Beijing Municipal Bureau of Statistics, 2006), a linear function was extrapolated from 2007 to $2010\left(R^{2}=0.895\right)$ based on the population in Beijing ( $P, 10^{3}$ persons) and agricultural GDP $\left(G_{\text {agri, }}\right.$ million US\$) using the multi-variant linear regression method in SPSS ${ }^{\circledR}$ 18.0. As a result, the number of output pigs $\left(H, 10^{4}\right.$ heads) is expressed as Equation (2).

$H=129.874+0.67 \times P+6.69 \times \mathrm{GDP}_{\text {agri }}$

Although the growth rate of the residential population $(P)$ was expected to be controlled within $1 \%$ annually in the 12 th Five-year Plan of Beijing (Beijing Municipal Commission of Population and Family Planning, 2011), the average population growth rate reached 5.07\% per year from 2006 to 2011, and the GDPagri rate increased by $9.0 \%$ (Beijing Municipal Bureau of Statistics and NBS Survey Office in Beijing, 2012). The results of the scenario analysis showed that the 2011 GHG emissions of $2.47 \times 10^{3} \mathrm{tCO}_{2} \mathrm{eq}$ at $R=10 \%$ will increase to $7.42 \times 10^{3} \mathrm{tCO}_{2}$ eq and $12.4 \times 10^{3} \mathrm{tCO}_{2}$ eq at $R=30 \%$ and $R=50 \%$ levels, respectively. These GHG emission values will chronologically increase by $21 \%$ in 2015 and $50 \%$ in 2020 , respectively, compared to the benchmark value in 2011. This soaring increase rate of GHG emission requires more attention to GHG reduction.

Optimistically, the SOC input by compost additions was deemed to enhance carbon sequestration (Whalen et al., 2008), offset GHG emissions from biofuel agriculture practices (Thelen et al., 2010) and substitute for $\mathrm{N}$ fertilizer (Gajalakshmi and Abbasi, 2008) through reductions in the GWP. However, they were conservatively not considered in this study to calculate the direct emissions. One study using the DNDC (Denitrification and Decomposition) model (Wang et al., 2012) simulated the 45-year exchange of GHG emissions in a crop field beginning from a baseline year of 2009 in China. The results revealed that manure additions would help to increase the SOC in soil, compared to the inorganic fertilizer treatment 


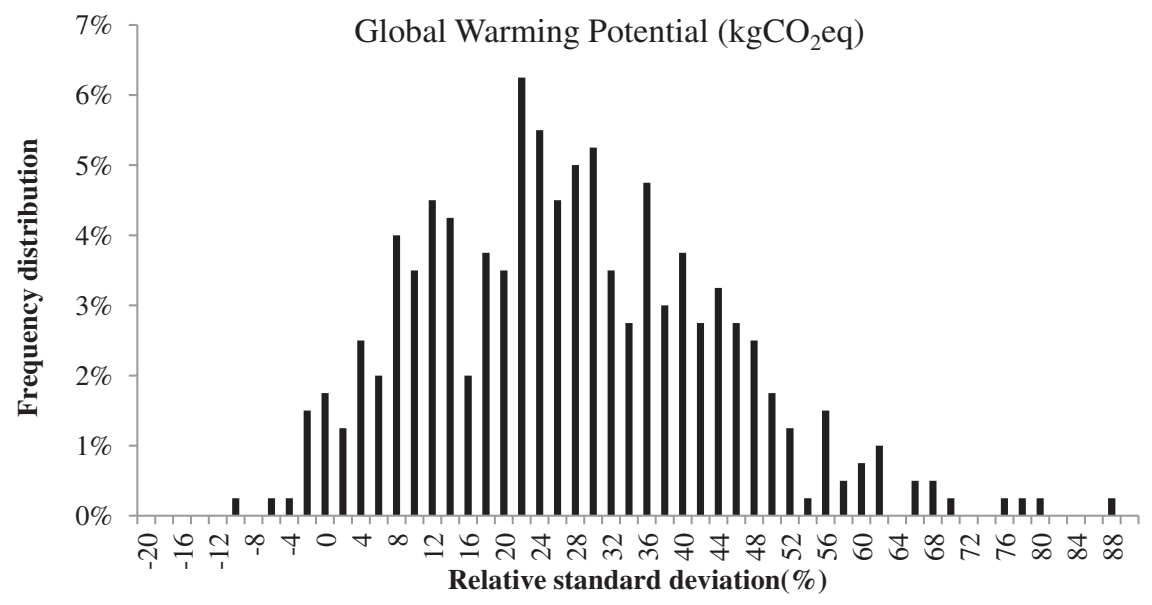

Fig. 6. Frequency distribution of global warming potential based on relative standard deviations from Monte-Carlo simulations.

(700 $\mathrm{kgN} \mathrm{ha}^{-1} \mathrm{yr}^{-1}$ ), by attenuating net GWP from 5853 to $5203 \mathrm{kgCO}_{2}$ eq $\mathrm{ha}^{-1} \mathrm{yr}^{-1}$ and enhanced the grain yield and SOC sequestration rate at the same time.

\subsection{Life cycle cost-benefit analysis}

As shown in Fig. 7, the operational cost of swine manure composting was US\$ $25.32 \mathrm{t}^{-1}$ compost (wet weight, moisture content at $25 \%$ ), which could be divided into freight costs (37\%) followed by labor costs (31\%), packaging (20\%), energy costs (11\%), and tractor rental fees $(0.9 \%)$. The selling price of the swine manure compost at US\$26.39 $\mathrm{t}^{-1}$ compost (wet weight, moisture content at $25 \%$ ) was much cheaper than the price of urea at US\$ $314.15 \mathrm{t}^{-1}$ (China Fertilizer Network, 2012). Although the main role of the compost acted as the soil amendment with abundant organic matter, the cost in inorganic nutrient form at $5 \%$ ( $25 \%$ of moisture content) was US\$703.73 $\mathrm{t}^{-1}$, while the urea was higher at US\$ $930.81 \mathrm{t}^{-1}$ (inorganic nutrient rate at $45 \%, 25 \%$ of moisture content). With government subsidies of US\$ $18.85 \mathrm{t}^{-1}$ compost, the gross profit of compost was US\$ $45.23 \mathrm{t}^{-1}$ compost for a net profit of US\$ $19.92 \mathrm{t}^{-1}$ compost, which was largely composed of government subsidies. Although there was a vast resource, huge amount and geographical proximity of farmyard organics in China (Li, 2011), the prospects of manure compost still lay in economic feasibility and market competitiveness. With an increasing loss in soil organic matter due to excessive fertilization (Zhang et al., 2010), the compost application would be more popular among farmers according to the

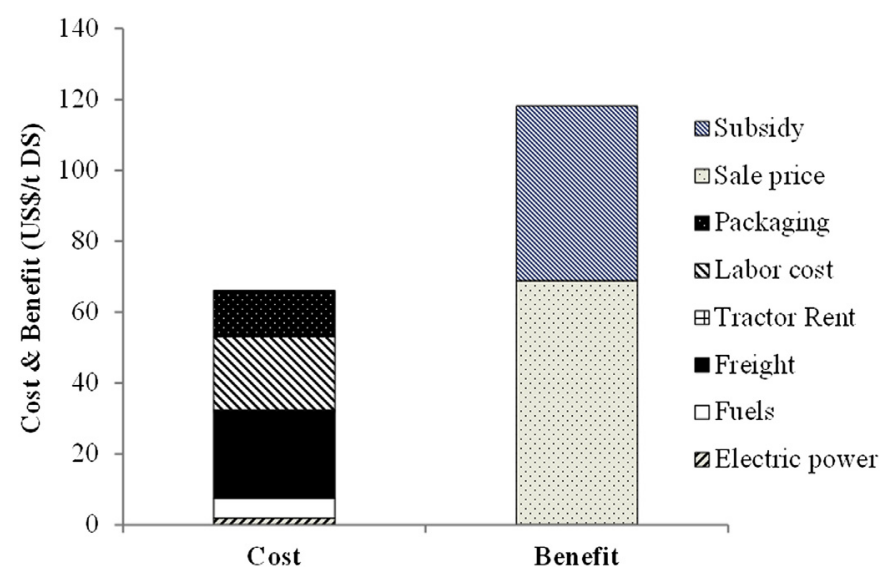

Fig. 7. The result of the life cycle cost-benefit analysis. governmental promotion and subsidy (Ministry of Agriculture of China, 2012) to supplement the organic humus in soil.

Illinois State University (Livestock and Urban Waste Recycling Research Team, 2004) examined the operational costs of two windrow composting processes that treated swine manure at a capacity of 2500 and 4500 tons year $^{-1}$, respectively. The average operational costs for the small and large capacities were US\$ 31.69 and US\$ 17.60 per ton of compost (moisture content not given), respectively, with their selling price ranging from US\$10 to US\$ 40 per ton of compost. These results were similar to those of this study, which showed that it would be profitable for the composting industry. Obviously, the marginal cost will be reduced with increased compost production scale, and the profit will be affected greatly by the price gap of between nitrogen-based chemical fertilizers such as urea and organic fertilizers. The land application of compost should therefore be encouraged because the compost is more costeffective than chemical fertilizers in terms of GHG emission and support from government subsidies.

\section{Conclusions}

Using on-site observations and an LCA analysis, the integrated GHG emission of swine manure composting and its land application in Beijing, China was investigated for the first time. The direct GHG emission factors for swine manure composting and land application of manure compost were $115 \mathrm{kgCO}_{2} \mathrm{eq} \mathrm{tDS}^{-1}$ (99\% as $\left.\mathrm{CH}_{4}\right)$ and $48 \mathrm{kgCO}_{2} \mathrm{eq}^{-1} \mathrm{tDS}^{-1}\left(74 \%\right.$ as $\left.\mathrm{N}_{2} \mathrm{O}\right)$, respectively. Considering the energy consumption, the total GHG emission factor of the entire life cycle was $240 \mathrm{kgCO}_{2} \mathrm{eq} \mathrm{tDS}{ }^{-1}$, including $48 \%$ from the direct GHG emission during swine manure composting and $20 \%$ from land application of the compost. The results of uncertainty analysis showed that the mean GHG emission value (300 $\mathrm{kgCO}_{2}$ eq $\mathrm{tDS}^{-1} \pm 13 \% \mathrm{RSD}$ ) was $26 \%$ RSD higher than the observed GHG emission factor $\left(240 \mathrm{kgCO}_{2} \mathrm{eq} \mathrm{tDS}^{-1}\right)$. The scenario analysis predicts increases in GHG emission by $21 \%$ and $50 \%$ in 2015 and 2020, respectively, compared to that in 2011. The life cycle cost analysis showed that swine manure composting and land application of compost would be a cost-effective method for animal manure management in China when considering GHG emissions.

\section{Acknowledgments}

This work is financially supported by the Special Fund for Agroscientific Research in the Public Interest (No. 201303091) and the 
National Natural Science Foundation of China (No. 41075090). The authors would like to thank PE International (developers of $\mathrm{Gabi}^{\circledR} 4.4$ ) for their technical support and database.

\section{Appendix A. Supplementary data}

Supplementary data related to this article can be found at doi:10.1016/j.atmosenv.2013.08.048.

\section{References}

Environmental Protection Agency of China, 2010. National General Survey of Pollution Sources. The Office of Pollution Census, Beijing. http://cpsc.mep.gov. cn/gwgg/201002/W020100225545523639910.pdf.

Barton, P.K., Atwater, J.W., 2002. Nitrous oxide emissions and the anthropogenic nitrogen in wastewater and solid waste. J. Environ. Eng. 128, 137-150.

Beijing Municipal Bureau of Statistics, 2006. In: Jiao, S., et al. (Eds.), Beijing Rural Statistical Yearbook. China Agriculture Press, Beijing.

Beijing Municipal Bureau of Statistics, NBS Survey Office in Beijing, 2012. In: Yu, X et al. (Eds.), Beijing Statistical Yearbook. China Statistical Press, Beijing.

Beijing Municipal Commission of Population and Family Planning, 2011. In: Liu, Z. et al. (Eds.), Yearbook of Population and Family Planning in Beijing. China Population Press, Beijing. http://www.bjfc.gov.cn/web/wenjian/renkounianjian/ 2011 nianjian.pdf.

Blengini, G.A., 2008. Using LCA to evaluate impacts and resources conservation potential of composting: a case study of the Asti District in Italy. Resour. Conserv. Recy. 52, 1373-1381.

Borken, W., Davidson, E.A., Savage, K., Sundquist, E.T., Steudler, P., 2006. Effect of summer throughfall exclusion, summer drought, and winter snow cover on methane fluxes in a temperate forest soil. Soil Biol. Biochem. 38, 1388-1395.

Breitenbeck, G.A., Schellinger, D., 2004. Calculating the reduction in material mass and volume during Composting. Compost Sci. Util. 12, 365-371.

Butler, J., Hooper, P., 2010. Down to Earth: an illustration of life cycle inventory good practice with reference to the production of soil conditioning compost. Resour. Conserv. Recy. 55, 135-147.

China Fertilizer Network, 2012. Daily Report of Carbamide of China Fertilizer Network. http://www.fert.cn/news/2012/7/11/20127111581234806.shtml.

Chinese Agricultural University, 1997. Coprology of domestic animals. In: Wang, X., et al. (Eds.). Shanghai Jiao Tong University Press, Shanghai.

Czepiel, P., Douglas, E., Harriss, R., Crill, P., 1996. Measurements of $\mathrm{N}_{2} \mathrm{O}$ from composted organic wastes. Environ. Sci. Technol. 30, 2519-2525.

Dong, H.-m., Zhu, Z.-p., Huang, H.-k., Chen, Y.-g., Shang, B., Tao, X.-p., Zhou, Z.-k., 2011. Pollutant generation coefficient and discharge coefficient in animal production transactions of the Chinese society of agricultural 27, 303-308.

European Parliament Council, 2000. Directive 98/69/EC Relating to Measures to be Taken Against Air Pollution by Emissions from Motor Vehicles and Amending Council Directive 70/220/EEC. http://eur-lex.europa.eu/LexUriServ/LexUriServ. do?uri=CONSLEG:1998L0069:19981228:EN: PDF.

Fukumoto, Y., Osada, T., Hanajima, D., Haga, K., 2003. Patterns and quantities of $\mathrm{NH}_{3}$, $\mathrm{N}_{2} \mathrm{O}$ and $\mathrm{CH}_{4}$ emissions during swine manure composting without forced aeration--effect of compost pile scale. Bioresource Technol. 89, 109-114.

Gajalakshmi, S., Abbasi, S.A., 2008. Solid waste management by composting: state of the art. Crit. Rev. Environ. Sci. Technol. 38, 311-400.

Guinée, J.B., 2002. In: Tukker, A., et al. (Eds.), Handbook on Life Cycle Assessment: Operational Guide to the ISO Standards. Kluwer Academic Publishers, New York.

Hao, X., Chang, C., Larney, F.J., Travis, G.R., 2001. Greenhouse gas emissions during cattle feedlot manure composting. J. Environ. Qual. 30, 376-386.

Hao, X., Chang, C., Larney, F.J., 2004. Carbon, nitrogen balances and greenhouse gas emission during cattle feedlot manure composting. J. Environ. Qual. 33, 37-44.

Huang, X., Han, Z., Shi, D., Huang, X., Wu, W., Liu, Y., 2010. Nitrogen loss and its control during livestock manure composting. J. Appl. Ecol. 21, 247-254.

Institute of Environmental Sciences, 2010. CML-IA Characterisation Factors. Leiden, U (Dutch) http://cml.leiden.edu/software/data-cmlia.html\#getting-and-usingthe-database.

IPCC, 2006a. Emissions from Livestock and Manure Management 2006 IPCC Guidelines for National Greenhouse Gas Inventories. IGES, Japan. http://www. ipcc-nggip.iges.or.jp/public/2006gl/pdf/4_Volume4/V4_10_Ch10_Livestock.pdf.

IPCC, 2006b. Biological Treatment of Solid Waste, 2006 IPCC Guidelines for Nationa Greenhouse Gas Inventories. IGES, Japan. http://www.ipcc-nggip.iges.or.jp/ public/2006gl/pdf/5_Volume5/V5_4_Ch4_Bio_Treat.pdf.

IPCC, 2006c. $\mathrm{N}_{2} \mathrm{O}$ Emissions from Managed Soils, and $\mathrm{CO}_{2}$ Emissions from Lime and Urea Application. 2006 IPCC Guidelines for National Greenhouse Gas Inventories. IGES, Japan. http://www.ipcc-nggip.iges.or.jp/public/2006gl/pdf/4 Volume4/V4_11_Ch11_N2O\&CO2.pdf.

Jiang, T. Schuchardt, F., Li, G., Guo, R., Zhao, Y., 2011. Effect of C/N ratio, aeration rate and moisture content on ammonia and greenhouse gas emission during the composting. J. Environ. Sci. 23, 1754-1760.
Kumar, S., 2011. Composting of municipal solid waste. Crit. Rev. Biotechnol. 31, 112136.

Law, Y., Lant, P., Yuan, Z., 2011. The effect of $\mathrm{pH}$ on $\mathrm{N}_{2} \mathrm{O}$ production under aerobic conditions in a partial nitritation system. Water Res. 45, 5934-5944.

Li, L., 2011. Manure Nitrogen Availability and its Substitution Ratio for Chemical Fertilizer Nitrogen, Chinese Academy of Agricultural Sciences (Ph.D. thesis). Chinese Academy of Agricultural Sciences, Beijing.

Lian, H., 2010. Formalization of Pig Farm Sewage Processing Cost and Benefit Analysis (M.S. thesis). Chinese Academy of Agricultural Sciences, Beijing.

Liu, H., Zhao, P., Lu, P., Wang, Y.-S., Lin, Y.-B., Rao, X.-Q., 2008. Greenhouse gas fluxes from soils of different land-use types in a hilly area of South China. Agric. Ecosyst. Environ. 124, 125-135.

Livestock and Urban Waste Recycling Research Team, 2004. Composting Swine Manure as an alternative Best Management Practice, Illini Sown. http://www. livestocktrail.illinois.edu/uploads/sowm/papers/p190-207.pdf.

Ministry of Agriculture of China, 2012. The Subsidy Program Guidance of Soil Organic Matter Enhancement. China, Beijing. http://www.moa.gov.cn/ govpublic/CWS/201206/t20120606_2751150.htm.

Ministry of Agriculture of China, 2011. In: Han, C., et al. (Eds.), China Agricultural Development Report 2011. China Agriculture Press, Beijing.

Ministry of Environmental Protection of China, 2011. The Policy of Technologically Control over Livestock Pollution, Policy of Pollution Control. Ministry of Environmental Protection of People's Republic of China, Beijing.

National Development and Reform Commission, 2004. The Initial National Communication on Climate Change of the People's Republic of China. National Development and Reform Commission, Beijing. http://unfccc.int/resource/docs/ natc/chnnc1e.pdf.

National Development and Reform Commission, 2013. Second National Communication on Climate Change of the People's Republic of China. National Development and Reform Commission, Beijing. http://www.ccchina.gov.cn/archiver/ ccchinaen/UpFile/Files/Default/20130218145208096785.pdf.

Novak, S.M., Fiorelli, J.L., 2010. Greenhouse gases and ammonia emissions from organic mixed crop-dairy systems: a critical review of mitigation options. Agron. Sustain. Dev. 30, 215-236.

Park, K.H., Jeon, J.H., Jeon, K.H., Kwag, J.H., Choi, D.Y., 2011. Low greenhouse gas emissions during composting of solid swine manure. Anim. Feed Sci. Tech. vol, 166-167, 550-556.

Pei, S., Zhang, Y., Liu, J., Lun, X., Mu, Y., 2011. $\mathrm{N}_{2} \mathrm{O}$ exchange fluxes from wheat-maize crop rotation system in the north China plain. Environ. Sci. 33, 3641-3646.

Recycled Organics Unit, 2006. Life Cycle Inventory and Life Cycle Assessment for Windrow Composting Systems. The Univ. of New South Wales, Sydney, Australia. http://www.recycledorganics.com/publications/reports/lca/lca.htm.

Shi, W., Norton, J.M., Miller, B.E., Pace, M.G., 1999. Effects of aeration and moisture during windrow composting on the nitrogen fertilizer values of dairy waste composts. Appl. Soil Ecol. 11, 17-28.

Smith, P., Powlson, D.S., Glendining, M.J., Smith, J.U., 1998. Opportunities and limitations for $\mathrm{C}$ sequestration in European agricultural soils through changes in management. In: Lal, R., et al. (Eds.), Management of Carbon Sequestration in Soil. CRC Press, Boca Raton, FL, pp. 143-152.

Suh, Y.-J., Rousseaux, P., 2002. An LCA of alternative wastewater sludge treatment scenarios. Resour.Conserv. Recy. 35, 191-200.

Thelen, K.D., Fronning, B.E., Kravchenko, A., Min, D.H., Robertson, G.P., 2010. Integrating livestock manure with a corn-soybean bioenergy cropping system improves short-term carbon sequestration rates and net global warming potential. Biomass Bioenerg. 34, 960-966.

U.S. Environmental Protection Agency, 2011. Synthesis of Comments Related to Accounting Approaches from EPA's Call for Information on Greenhouse Gas Emissions Associated with Bioenergy and Other Biogenic Sources. Washington, DC http://www.epa.gov/climatechange/ghgemissions/biogenic-emissions.html.

USEPA, 2002. Solid Waste Management and Greenhouse Gases: a Life Cycle Assessment of Emission and Sinks. Environmental Protection Agency, USA http://www.epa.gov/climatechange/wycd/waste/downloads/fullreport.pdf.

Wang, J., Zhang, X., Liu, Y., Pan, X., Liu, P., Chen, Z., Huang, T., Xiong, Z., 2012. Modeling impacts of alternative practices on net global warming potential and greenhouse gas intensity from rice-wheat annual rotation in china. PloS One 7 (e45668), 45661-45669.

Whalen, J.K., Benslim, H., Jiao, Y., Sey, B.K., 2008. Soil organic carbon and nitrogen pools as affected by compost applications to a sandy-loam soil in Quebec. Can. J. Soil Sci. 88, 443-450.

Wu, W., Li, L., Lu, H., Wang, C., Deng, H., 2012. Mechanisms of nitrous oxide emission during livestock manure aerobic composting. Chinese J. Appl. Ecol. 23, 17041712.

Xiong, Z., Xie, Y., Xing, G., Zhu, Z., Butenhoff, C., 2006. Measurements of nitrous oxide emissions from vegetable production in China. Atmos. Environ. 40, 22252234.

Zhang, W., Wang, X., Xu, M., Huang, S., Liu, H., Peng, C., 2010. Soil organic carbon dynamics under long-term fertilizations in arable land of northern China. Biogeosciences 7, 409-425. 